\title{
“Ära päri - saad ruttu vanaks!" Tabudest ja mahavaikitud teemadest argisuhtluses ühe samaealiste tutvuskonna näitel
}

\author{
Pille Kippar \\ Tallinna Ülikooli humanitaarteaduste instituudi emeriitprofessor \\ piki@tlu.ee
}

\begin{abstract}
Teesid: Inimsuhtlemises on ikka olnud teemasid, mida kõigile ei räägitud ja igaühega ei arutatud. Käsitlused ja suhtumised erinevad ka põlvkonniti. Avan artiklis vaikimise teemat oma põlvkonna - praeguseks pensioniikka jõudnud inimeste seisukohalt. Aluseks on sügisel 2019 otseste küsitluste ja arutluste teel kogutud andmed ning teated ligi pooleltsajalt informandilt, lisaks mälestused ja kaudsed tähelepanekud, ka raadiosaated. Küsitlesin lahtirääkimata või tabuteemade kohta perekonnas, töö- või sõprusringis, aga ka kokkupuudetes juhututtavate või võhivõõrastega. Arutluste teema laienes ja kasvas nagu suulisele rahvaloomingule omane: jutt jutust, sõna sõnast. Järgnevas on olulisemad korduvmotiivid grupeeritud teemavaldkondadeks ning varustatud illustreerivate lõikudega kogutud tekstidest.
\end{abstract}

Märksõnad: delikaatsus, kogemuslood, perefolkloor, poliitiline hirm, tabunarratiivid, vaikimine

Oma kooliaega ja õpetajaid Karl Atra ja Helmi Tohvelmanni meenutades tõdes EMTA VII lennu lõpetanud Lembit Peterson: "Õppisime sellest, mida nad rääkisid, aga vast veel rohkem sellest, mida nad ütlemata jätsid...”(Lennud, ETV2, 8.09.2019). Paljudes olukordades oligi vaikimine tõenäoliselt kõige turvalisem või konkreetset olukorda arvesse võttes ainuõige lahendus. Juhindudes küsimustest, millest siis ei räägitud ja miks, võtan fookusesse teemad, mis meenusid eakamatele, praeguseks pensioniikka jõudnud poolesajale inimesele kõigepealt. Rahvaluule ja mälestuste kogujad teavad (vrd nt Kõresaar 2003: 60), et esmalt tulevad jutustajatele meelde lapsepõlves kuuldud või läbielatud seigad, eriti sellised, millest elus väga palju olenes või mida väga keelati. Need kirjeldused püüan järgnevas esitada üheksaks olulisemaks kategooriaks korraldatult ja koos põgusa analüüsiga. On ju mõnedki uurijad toonitanud isiklike mälestuste olulisust kollektiivses mälus ja ühiskondlikus väärtusteloomes, näiteks George Marcus leiab, et kollektiivse mälu olulisimaks vahendajaks ongi isikliku elu seikade jutustamine, mitte ametlikud avalikud mälurepresentatsioonid (Marcus 
1993: 316; vt kollektiivse mälu ja autobiograafilise tõlgenduse vastastikmõjust nt ka Kõresaar 2005).

Suur osa kogutud mälestusi puudutab Teist maailmasõda ja sellele järgnenud aega, 20. sajandi keskpaika, toonaseid keelde ja tabusid, millest mõnesid arvestatakse siiani (paljud uurijad on rääkinud sellises vaikimise kontekstis koguni rohkem või vähem teadlikust kollektiivsest amneesiast, vt nt Korkiakangas 1997: 9). Püsivaks ja järjepidevaks vaikitud teemaks on jäänud isikliku eluga seostuv delikaatsus ja meditsiinilised (haiguse) probleemid, ka peresaladused. Toonaste tabuteemade hulgast on hiljem valdavalt kadunud poliitilise võimu hirm, julgelt ja avalikult käsitletakse puberteediiga, ent juurde on tulnud isikuandmete ja sissetulekute salastatus. Järgnev on sissevaade esmalt meenunud, kogu ühe põlvkonna elu mõjutanud teemadesse.

\section{Sugulase/kolleegi säästmine ärritusest või ebameeldivusest}

Laekunud materjali põhjal tundub, et eakamate puhul võib täheldada rohkem delikaatset empaatiat kui nooremate hulgas, aga on ka vastupidiseid näiteid.

Proua Eljo (1938) väitis, et tema peres pole küll ühestki teemast kõrvale hoitud ega midagi varjatud ja töölgi masinate taga, kus oldi koos vene neidudega, räägiti kõigest. Kui aga tuli jutuks, mida tema enda lapsed teda säästes on rääkimata jätnud, ilmnes mõndagi. Lapselapse haigusest ja puudulikkudest hinnetest koolis sai ta alles hiljem teada, aga siis olid juba pahandused likvideeritud ja asjad korras.

Pärast infarkti hoidis Herbert, nagu arst oli soovitanud, erutavatest asjadest eemale; veel rohkem tegid seda aga tema eest abikaasa ja teised. Herbertil võimaldati rahulikult oma tööd teha - kriitilised probleemid osakonnas aeti korda ilma temata ning hoolimata väga suurest ruumikitsikusest säilitati tema isiklik töölaud ka siis, kui ta ise juba mujal töötas. (Pille ühest Tartu asutusest 1970. aastatel)

Ema Linda pidurdas oma vanemat õde Mariet kellegi tuttava kohta ebameeldivat lugu edasi jutustamast. Kui Marie esitas korduvalt väite: "Aga see on ju tõsi!”, vastas ema: "On küll, aga mis sina sellest siis veel kordad" või: "Nojah, aga kas sul on siis vaja seda paha juttu talle aina nina peale kirjutada?" Mariel ei jäänud muud üle, kui lisada: "No ma tahan ju ka midagi uut rääkida...”(Pille) 


\section{Oma pere rääkimata asjad ja peresaladused}

Vaikiti poliitiliselt tundlikest seikadest, aga ka pikantsetest eraelulistest juhtumitest, mille puhul kardeti, et nende kaasteadmine võiks panna lähikondsed keerulisse olukorda (näiteks tekitada ohu, et lapsed saladuse kogemata sobimatutele isikutele paljastavad) või neid emotsionaalselt laastada. Mälestustest selgub, et mõnigikord polnud noorematel inimestel aega või nad ei soovinud vanemate pikki jutustusi kuulata, hiljem aga tundsid pere mälestustest või lugudest puudust.

Tädi Elli (snd 1893), oli kui elav entsüklopeedia, kes kogu Kuusalu kihelkonna inimeste ja perekondade lugu täpselt teadis, mäletas ja meelsasti jutustas. Tütar Luule asus pensionipõlves Valklasse suvekodusse ja käis pärast ema surma täditütar Pillelt Valkla küla või sugulaste kohta pärimas, mida tema ema ühe või teise asja kohta rääkinud oli: "Tõrjusin ema heietused tagasi; ta tahtis aina nendest Valkla ja Kuusalu asjadest rääkida... Tüütas lausa ära...” Ongi vist nii, et peremälestuste, mitmete mineviku asjade vastu tekib huvi alles vanemas eas. (Luule, Pille)

Kurameerimisest, eesseisvast abiellumisest ei räägitud; peeti salajas, kuna valitses ebausk, et liigne ja varajane lobisemine või teatamine põhjustab ebaõnne. Vahel taheti ka pulmakutse saajaid üllatada. (Vete)

Toomas (1960) ei teadnud oma "soomepoisiks" olnud isa Karli elust ega saatusest 1940. aastatel: "Ei osanud küsida, ei huvitanud; polnud päevakorral; ta ise ei rääkinud... saime hiljem harva kokku..."

Minul jälle sõjaaegne mälestus (olin siis jõudnud teise klassi). Ühel sügisõhtul, 1944, tuli meile Koluveresse vaikselt kolm võõrast meest võõras mundris. Need olid augustikuus Soomest Paldiskisse saabunud IR 200 mehed, nn soomepoisid. Tulid Eestisse tagasi oma kodumaad kaitsma, aga siin oli siis juba sõjakaos; ma ei tea, kas meil olid sees veel sakslased või juba vene väed. Üks mees, Karli, tuli oma abikaasa tädi (= minu ema) juurest abi paluma. Ema ehmatas ära. Meestele anti süüa, lasti end puhtaks pesta, pandi puhkama ja hakati tsiviilriideid otsima. Isa kapp sai päris hõredaks. Sõja ajal polnud ju poest üldse midagi saada. Kaks meest läksid varsti ära, kolmas oli haige ja see jäi tahatuppa isaema voodisse end ravima. Mingi haav või haavand oli. Nüüd seletati lastele, et sellest mehest ei tohi mitte kellelegi rääkida; et ta üldse meil on ja mis mees. See on meie pere saladus. Et kui terveks saab, peab kohe ära minema. Nii läkski. (Pille) 
Teine Karl oli isa vend onu Karla, kes öösiti Ameerika Häält kuulas. Olime suviti isa kodus vanaema ja onu-tädi juures. Karla kuulas kaks korda öö jooksul - kella kolmveerand viie ja kolmveerand kuue ajal - seda raadiot, ja päeval vesteldi kuuldust külameestega. Tädi keelas, et ära kuula, käriseb ju, lapsed ei saa magada; meile just meeldis niisuguse keelatud asjaga kursis olla. Ikkagi väike risk ja huvitav. Kodus proovisime ise ka, aga selle lõpetas ema kohe ära: no laste lõbu pärast küll ei taha Siberisse sattuda. Niisugune oht oli. (Pille)

Mõndagi asja ei räägitud lapsele, kardeti, et ta sobimatul ajal kellelegi välja lobiseb. Pere saladused - näiteks suitsiidid, kroonilised ja parandamatud haigused, nendest ei räägitud ei võõrastele ega ka oma lastele. Nendest sageli ei teatudki. (Merike)

Kui oli vaja lapse eest midagi varjata, räägiti mõnes muus keeles, vene või saksa keeles... Siis kui laps on väiksem; hiljem enam ei saa... (Malle)

Silmi (1937) õppis õpetajaks, töötas Pärnumaal:

Taheti panna pioneerijuhiks - ei taha, ei sobi mulle... Siis ütlesin, et olen usklik... Hakati jälgima... Et kirjuta avaldus, et sa ei taha/saa/hakka pioneerijuhiks...Tulin ära. Siis läksin uuesti kooli, medkooli... Tütar Kaire ei teagi seda... temale ma pole rääkinud, ta pole küsinud... kodused toimetused kogu aeg... (Silmi)

Elasin sõja ajal vanaema juures Hiiumaal. Meil oli saun ja naabrinaine tegi meie juures puskarit. Saunakatla puust kaane sees oli keskel auk. Et mis see on? "Sealt ikka katsuti, kas vesi on juba soe," - nii vanaema ütles, kui selle augu kohta küsisin. Ükskord läksin jälle sauna, siis nägin - tilkus ja vulksus - et mis see ikka on? Nisukesed torud ja... "Ei-ei! See pole mitte midagi, ära sa sinna mine! See ei ole praegu meie asi” [---] See katel oli olnud Süllata Johannese vana puskariajamise katel. Õe poeg, tark ja hakkaja poiss, hakanud omale ise autot tegema, saaginud torud katki... No mis sa enam teed... Neil oli siis juba teine katel ka olemas, siis see sai meile. [---] (Luule 1932)

Elasime Paides. Vanemad läksid lahku. Mulle anti valida, kelle juurde jään. Valisin isa. Läksin Nõmme Gümnaasiumisse (siis 10. Keskkool) 5. klassi. Suvel olin ema juures. Koolis tuli küsimus, et miks su ema siis Paides on. Ütlesin (luiskasin) et ta ei saa kohe siia tulla. Mul oli piinlik, et ema-isa lahku läinud. Kui mulle sündis poolvend, järgmisel aastal, siis tuli asi avalikuks. Hakkas kohe kergem... (Merike) 
Isa, kes paljusid maailma asju lastele õpetas ja seletas, oma prassimistest buršidega ega ülikooli poolelijätmisest ei rääkinud. Olin tema lahkumisel 21 - küllap edaspidi oleks rääkinud. (Mari)

Metsavenna-asja ei tohtind rääkida. Lihula roogudes, seal nad varjasid endid... Siis küüditamisest, et kes olnud koputaja, seda ju teati või arvati... Et uusmaasaajad, nemad ju said kasu. Ja põgenemised, et kes läks ja kuidas õnnestus... Ameerikast tuli sugulane siia, nüüd, palju hiljem, siis rääkis seda põgenemist. Meil ei räägitud ka seda, mida teati. Äraandmist kardeti, anti üles - kui olid tülis, siis muudkui andis parteikomiteesse teada. Kes ennast üles töötasid, siis anti teada... Kaitseliit oli... enne sõda ja sõja ajal. Ruudi (onu) põgenes, ei läind sõjaväkke, varjas ennast. Sellest pärast ei räägitud. (Silmi)

Isa viidi ka ära, olid seal, ootasid... Ema ei teadnud, kas tuleb tagasi. Isa läinud peldikusse, selle ajaga viidud teised ära. Tal polnud muud kui tuli koju. Siis ei räägitud kaua aega, et tuli koju... Saanika külas olid lahingud, aeti mingit naabrimeest taga, aeti metsavendi taga. Madinad olid hulk aega ... õnneks olime metsa sees. Vend Martin sündis 1944, just siis venelased tulid, tulid sisse - ema näitas, et just sündis, pisike... Siis vaatas, naeratas, ei teinud midagi. (Silmi)

Olime jälle hirmul, kui venelased sisse tulid. (Ridala) kirikumõisas pandi lambaid peale. Ega ma isa käike ka täpselt ei tea, - kuda vähem teadjaid, seda parem. Võib olla oligi, aga sellest ei räägitud. Olime ju lapsed. Saksa ajal... üks Jaks oli, otsiti taga, muudkui kahtlustasid, käisid püssid käes... - Ja usklikke kiusati taga. Vilma oli teadlane, ihtüoloog, ta oli usklik, ei saanud tööd. Tiit (hiljem Valkla koguduse jutlustaja) lõpetas EPA, ei saanud ülikooli. (Silmi)

Gattšina vanatädi Liina elas koos abikaasa Madisega pärast sõda Kehras. Sakslane tõi nad sõja ajal Eestisse. Nad olid kaasa toonud oma pere reliikvia - väga huvitava Gattšina elu kajastava vana fotoalbumi. Sealsete piltide järgi näitas ja jutustas tädi, kes pildil on ja kuidas tema elu läks. Ühel pildil oli uhkes mundris noor mees. "Kes see on? Mis munder see on?” - “Ära seda küsi! Ära päri - saad ruttu vanaks!” See oli onu Madise noorepõlve pilt tsaariarmee mundris. Venemaal oli nõukogude ajal nii, et ühe mundri kandjat võidi teise valitsuse ajal kõige suuremaks patuseks pidada ja vastavalt karistada. Nii saadeti paljud Siberisse või lasti lausa maha. Seda valitsust kardeti. Üldse ei julgetud paljusid asju karistuse kartusel rääkida, vähemalt lastele mitte. (Malle) 
Ka kõige lähemate kolleegidega Kehras ei räägitud meie pere käimisest palvemajas ega sealsetest ettevõtmistest. Me ei käinud Kehras, käisime palvemajas Tallinnas, metodisti palvemajas. Kehras oli see ka olemas, aga me seal ei käinud. Minu õpetaja teadis, aga sellest ei räägitud. (Malle)

Punased passid olid, tegelikult parteipiletid - nendest ei räägitud meie peres kunagi halvasti. Aga pärast pü̈̈ti üldse mitte rääkida. [Jutustaja Malle isa oli punaarmee poole peal, ehkki peret oli varem, enne sõda Gattšinas represseeritud.] Teine vend jäi Velikije Luki alla, isa (Juku) tuli "punase passiga" sõjast tagasi. Isa oli Tallinnas ja hiljem Kehras parteisekretär. Tal oli kehv tervis, suri varsti. Ema pöördus igale poole, teda aidati kui üksikema või parteisekretäri leske. Vanem vend Paul jõudis enne sõda Leningradis ülikoolis käia, töötas Tallinna Polütehnilises Instituudis. (Malle)

Praegu on Soomes mitmeid mineviku suhtes keeluteemasid, neid ei puudutata. Paljudest perekonna asjadest ei räägita, vähemalt minu kuuldes mitte. (Malle, on ca 10 a tagasi abiellunud Soome ja suhtleb seal oma eaka mehe sugulastega)

Vene koolide eesti keele õpetajate kirjapanekute hulgas (Tallinna Pedagoogikaülikooli kaugõpe 1990. aastatel) on mitmeid, kus vanemad ja vanavanemad keeldusid üldse oma minevikust jutustamast: selles polevat olnud midagi mäletamisväärset ega head. Kui tütar viis jutu minevikule, muutus isa süngeks ja vaikis, memmeke hakkas nutma ega soostunud rääkima midagi: "Ära kisu vanu haavu lahti, ma tahan kõike unustada!" Eestis elatakse sõjast saadik; minevikust pole siinsündinud tütrele räägitud kunagi. Temal minevikku polegi (Kippar 2000: 227).

\section{Riigisaladused. Ametlikud keelud. Tabuteemad}

Nõukogude perioodil sai rahvale selgeks, et mõnedki varem tavalised teemad tuli uue korra ajal hoolikalt läbi mõelda, vestlustes nende kohta pool suud kinni hoida ning vastavalt seltskonnale otsustada, millest rääkida ja millest mitte. Mälestustest ilmneb tõdemus, et teinekord oli vaja mõni isik või oma eluseik maha vaikida, pidi arvestama nn raudse eesriidega, keelatud trükiste ning välismaal elavate sugulastega ja postisaadetiste kontrolliga.

Kui Eesti Õpetajate Meeskoori uus liige tuli, pidasid teised aru, kas on peet või redis - vastavalt siis, et kuidas on uue laulja poliitiline usaldatavus. (Aleksander, 1970.-1980. aastate kohta) 
Lastekodusse saadeti salastatud nimekirjad nendest trükistest, mis olid keelatud ja tuli raamatukogust kõrvaldada. Neljakümnendatel. Neil dokumentidel oli paremas ülanurgas tempel või sõna, et salajane. Mõnikord eesti, siis jälle vene keeles. Kuna Kosejõe Koolkodu oli asutatud alles sõja ajal, polnud seal varasemat ehk sõjaeelset kirjandust, aga õpetajad said teada, keda [s.t autoreid] kõike ei tohinud raamaturiiulis olla. See oli riigipoolne salastatus. Kel oli juhust vene ajal välismaalt raamatuid saada, märkas sageli raamatukaane või tiitellehe paremas ülanurgas - just nagu lastekodusse saadetud nimekirjadel - lillat kolmnurkset templit. Sain 1986. aastal neid ise mitukümmend, kui Soome Kirjanduse Selts mulle mu "Loomamuinasjuttude" kataloogist hulga eksemplare saatis. (Pille)

Erakonnad on omaette asi. Näiteks Ameerika või Suurbritannia ühiskonnas välditakse siiani mõnigikord poliitiliste erakondade teemat demokraadid ja vabariiklased. Et kui kuulud ühte, siis teise ideedest pole midagi rääkida. (Heli)

Mul omal on mitmeid seltskondi, kellega harvemini kokku puutume. Näiteks käime vahel koos tudengiaegse maleva-seltskonnaga. Peredega koos ei käida, kuigi paljud leidsid sealt elukaaslase. Siis ju polnud kellelgi peret; ja nüüd räägime kõigest muust, aga oma peredest ei tule meeldegi rääkida ega küsida. (Heli)

Ka “Filoloog '59" kokkusaamistel ei puudutata EV erakondade ideoloogiaid; hakkas see Tiit Vähi Koonderakonnast. Toonane peaminister oli Vello ja Kalli suvilanaaber ja hea perekonnasõber ning aatekaaslane. Muud minu sõprusringi "tüdrukud" austavad erinevate erakondade ideoloogiaid (Sotsiaaldemokraadid, Isamaa) ja kokkusaamistel me neid teemasid ei puuduta. (Pille)

Minu ema töötas postkontoris. Haapsalus. Ta oli kirjade sorteerija. Sel ajal oli poliitiline kontroll väga tugev. See pidi olema viiekümnendatel, Stalini ajal, ma olin alla 20, käisin seminaris. Elasime kahekesi, isa oli siis juba ära läinud. Ema oli erilise kontrolli all, teised postkontori töötajad ei pidanud teda nägemagi. Mina ei tohtinud ka sinna minna. Koridorist läks kaks ust, tema ühes ruumis, teine oli taga; seal olid julgeoleku mehed, 3-4 meest NKVD toas. Need ei näidanud oma nägu, kapuutsid olid peas. Eks ta käimisest, sammudest ja kogust sai aru, missugune mees oli... Sinna taha ruumi ta ei käinud, kirjad pandi läbi luugi. Ja ei tohtinud 
kellelegi rääkida. Kui post toodi, kallati kastid või kotid tühjaks; kas olid Haapsalus posti pandud või jälle mujalt tulnud. Oli nimekiri, valiti mõned välja, kelle kirju ei tohtinud kohe edasi saata. Julgeolek valis ja kontrollis veel üle. Kui uue aasta post tuli, oli hirmsasti tööd. Paar korda pandi ta mõtlema, et kas on teinud kõik nagu vaja-korra pidi istuma terve öö, ainult tool oli... et kuku kasvõi maha. Ma ei teadnud kodus midagi, hirm oli... Kui ükskord koju tuli, siis ütles, et mul oli nii palju tööd. Ja sellest me ei räägi. Pärast läks meelest ära - siis ka ei rääkinud, et mis siis tegelikult juhtus. Aga ükskord ma siiski käisin seal. Läksime koos; võtsin kingad jalast ära ja läksime sisse. Ema pani näpu suu peale, et ma ei räägiks ega köhataks - võidi kuulda. Seal ruumis võidi kogu aeg kuulata. Mind kontrolliti ka, mitu kuud, kui olin seminari lõpukursusel. Paar kirja olid mitu kuud nende käes "hoiul”. Ja vahel olid lahti võetud ega enam korralikult kinni pandud. (Vete)

Need koolikaaslased, kes elasid maal, pandi kolhoosi, kui kolhoosid hakkasid tulema. Ei tahtnud ju, kartsid kolhoosi ajamist. Siis kirjutasime. Ema ütles, et mis sa teed niisuguseid kirju. (Vete)

Paide gümnaasiumis õpetati abiturientidele enne lõpetamist (1954) dokumentide koostamist: kirjuta avaldus ja elulookirjeldus ning täida ankeet (mahtu mitu lehekülge, vanematest-vanavanematest ning õdedest-vendadest saadik). Helju kirjutas nagu oli, pani kõik nõutud sugulased ning õed-vennad kirja. Varsti soovitas koolidirektor, vana Aimla, tal eravestluses ankeeti muuta - jätta pärast sõda noore mehena metsavendade haarangu ajal ära viidud ja hiljem maha lastud vanem vend ankeedist täiesti välja, maha salata. Et muidu poleks lootust ülikooli pääseda. Helju jutustas sõbrannadele aastakümneid hiljem, et tal oli nii-öelda patt hingel - ankeedis maha salatud vend, tubli poiss ja talu pärija. Aga pärida polnud ju ka enam midagi, talud võeti kolhoosi.

Ettekandes "Tundmatu Vello Tarmisto" (Tallinna Teadlaste Maja koosolekul 16.10.2019) tutvustati ühe Eesti NSV akadeemiku ja teadusmehe seni üldsusele teadmata elulugu. Ettekandja, majandusteadlane Kalev Kukk mainis, et nõukogude ajal ju kolleegide eludest midagi ei teatud, ei räägitud. Tarmisto toimikus leidus võõrkeelseid kaebusi selle kohta, et mees oli nooruses (skaudina, 1930. aastatel) koos sõpradega Lääne-Euroopas ringi rännanud; et ta vanavanematel olnud Mulgimaal jõukas eesrindlik talu - olid kulakud ja järelikult kuulus ta kapitalistide hulka ja ei vääri hoolimata Punaarmees võitlemisest ja kahest Punatähe ordenist teaduskraadi. Kui mees siiski ENSV-s teadusinstituudi direktoriks tõusis, pidi ta tõenäoliselt vahetama identiteeti. Varasematest tõekspidamistest on erinevatel põhjustel ja poliitilise surve all 
mõnedki loobunud. Ettekandes "Patukahetsustest" rääkis möödunu mahasalgamistest Tallinna Pedagoogikaülikooli kultuuriteaduskonna eesti kultuurilugu käsitleval kolmandal konverentsil "Eesti kultuur 1940. aastate teisel poolel" (1998) Mirjam Peil. Arhiivid säilitavad sõjajärgseid patukahetsuskirju mitmelt eesti teadus- ja kultuuriinimeselt nagu Harri Moora, Ado Vabbe, Elmar Kits, Voldemar Vaga, Karin Kask.

Seda, et meie kursusekaaslane Elmar (1930) ka kinni oli, sain teada alles hiljuti Tartus. Ei räägitud ju, polnud tavaks. (Merike)

Mõnel Tartu õppejõul oli probleem Türilt pärit Eilartitega. Kui ei tahetud või ei tohitud ülikooli vastu võtta, kukutati sisseastumiseksamil läbi. Nii juhtus Mare Eilartiga, Jaani õega - kukkus ajaloo eksamil läbi ja ei saanud ülikooli sisse. Jaan tahtis TRÜ-sse, bioloogiasse, aga ei saanud; sai siiski minna EPA-sse, agronoomiasse. Hakkas ise vabatahtlikult bioloogia loengutel käima. Ju siis seda ei keelatud. Pärast toodi bioloogiasse üle. (Merike)

Eesti Vabariigi akadeemik Georg Liidja (1933-2018) lõpetas töölisnoorte õhtukeskkooli 1952. aastal. Tahtis astuda Tallinna Õpetajate Instituuti, aga ei võetud vanemate pärast vastu: isa oli olnud Eesti Vabariigi tegevsõjaväelane, hukkus sõjas; ema oli lahkunud Inglismaale. Siis pü̈̈dis astuda Tartu ülikooli, oli probleeme; aga dekaan Anatoli Mitt võttis ta vastu, fü̈̈sikasse - kohti ju oli. Mitt julges. Mees töötas ennast üles. Ise, üksi ja oma jõuga. (Marja)

\section{Tervis: haigused ja seksiteema}

Praegustel eakamate inimeste kokkusaamistel räägitakse sageli tervisest, haigustest ja ravimitest. Varem ulatus see teema harva pereringist välja. Isegi oma lapsed ei pruukinud esivanemate haigustest teada. Veel vähem puudutati inimeste füüsilise läheduse ja sugulise läbikäimise teemat (vrd sarnane järeldus Latvala 1999, kus autor toob muuhulgas näite, kuidas jutustaja räägib oma vanaema vallandamisest teenijakohalt ja hiljem uude kohta suundumisest koos vahepeal sündinud lapsega, kuid tõsiasja, et eelmisest kohast lahkumine oli seotud seksuaalsuhtega, millest see laps sündis, aimab kuulaja vaid kaude). Selles valdkonnas jäi sõjajärgne põlvkond täiesti ilma ettevalmistuseta ja hilisemad etteheited vanematele, mida mälestusteski mainitakse, olid põhjendatud. 
Haigustest väljaspool peret rääkida ei peetud heaks tavaks. Rahvaarstidest, eri tasanditel ravijatest pole avalikult väga palju räägitud; see oli n-ö tabuteema: arvati, et kui kõik teavad, siis ravi ei mõju. Neil, ravitsejail, oli-sõltuvalt võimetest - erinev levikuareaal. Ometi on teatud võimetega inimesi Eestimaal olnud alati ja nad on saanud hädalisi aidata. (Mare)

“Kuidas su tütrel läheb?” - "Minu tütrel? Pole viga... Aga kes rääkis - me pole sellest kellelegi rääkinud?” [Tütar oli sattunud rinnavähiga tohtrite kätte; opereeriti õnnestunult.] (Karin, Pille, ca 2000)

Doktor küsitles 2019. aastal sugulaste [krooniliste] haiguste üle, imestades: "Kas sellest pole peres räägitud? Kas teie ei tea oma sugulaste haigustest?” (Pille)

Olin ainuke laps peres. Mu emal olnud teise raseduse ajal avarii-rasedus katkes, kui ta midagi tõstnud oli või... Kui mina last ootasin, hakati mind eriliselt hoidma: ema ja tädid ja vanaema ja vanavanaema... Siis alles kuulsin sellest, ja et miks üksik laps olen. Ei olnud vaja rääkida. "Ah, need olid need naiste asjad," vastati lastele, kui tekkis küsimus, miks Liina on vaeslaps, miks tema ema suri. Seda teemat ei arendatud, sellest ei räägitud. Ma ei tea siiani. (Marja)

Onutütrel polnud lapsi. Küsimusele, miks nendel järeltulijaid ei ole, vastas ta ikka, et pole aega: kolhoositöö ja majaehitamine ja... Kui Silvi üksikuks jäi ja teda sagedamini külastasin, sattusime sellest omavahel rääkima. Mõne abieluaasta järel oli abikaasa pärinud, miks tal [neil] lapsi pole. Proua pöördus arsti poole, teda uuriti, tehti mitmed proovid, leiti esialgu kõik korras olevat ja paluti lähemas tulevikus ka mehel polikliinikusse tulla. Mees: "Mina? Miks mina? Ei! Miks mina peaksin minema? Ei-ei!" Ei läinudki. Ja last ei sündinud. Kaua valitses ju ühiskonnas seisukoht, et lastetuses saab süüdistada ainult naispoolt; viimastel kümnenditel on meditsiin tõestanud ka vastupidist. (Silvi, Pille)

Kui esitati küsimus emale: "Kas sa poleks tahtnud, et sul oleks olnud rohkem lapsi?” tuli vastus: “Kaks on, üks sai vahepealt otsa ka...” Mingeid küsimusi ei saanud enam esitada. Kõik. (Pille)

Olin tookord 6. või 7. klassis, suur tüdruk. Ema ja tädi Olga arutasid mingeid kuuldud sündmusi, et kedagi oli vägistatud. Pärisin, mida see tähendab, et vägistatud. Mõlemad õekesed punastasid, kangestusid tükiks 
ajaks... Lõpuks tädi kogus end varem ja vastas: "Noh, tuli kallale, tahtis paha teha, kägistada.” Rahuldusin sellega. (Pille)

Järvamaa rahvaluule kogumise ekspeditsioonil (1966-1967) juhatati mind Koeru hooldekodu naabrusse endise ämmaemanda juurde. Pärisin rahvapärase sünnikombestiku kohta. Vana daam küsis hakatuseks: "Kas ise sünnitanud oled?" - "Ei ole." - "Kas mehega maganud oled?" - "Ei ole." - "No siis me sellel teemal ju rääkida ei saa." Materjali teadja välistas teemasse mineku - küsitleja polnud pädev. Muutsime teemat. Sain teavet ravimtaimede kasutamise kohta. (Pille)

Väga isiklikke asju ei räägitud. Kallistamist ja fü̈silist kontakti ei räägitud kellelegi; emale ka mitte. Isegi kui oli emaga hea suhe. (Vete)

1959. aastal Haapsalu Ridalasse koolmeistriks minnes sain õpetamiseks kooli vanima, esmakordselt avatava 8. klassi, kus oli sel aastal ka tavapärasest veel vanemaid õpilasi, nn ülekasvanuid. Klassijuhataja ülesannete hulka kuulus terviseõpetus, millest eriti puudust tunti, aga kooliprogrammis seda siis veel polnud. Sain hakkama puhtusekontrolli, toidusedeli ja kuulmise-nägemise teemadega, aga kui tuli teemaks, et kust ja kuidas tulevad lapsed, mida teha ja kuidas käituda vastassugupoolega, jäin hätta. Isiklikku kogemust polnud, trükiseid hoopiski mitte, hädast aitas välja bioloogiaõpetajast naabrinaine. Tänini kinnitavad mu endised kaaskoolmeistrid, keskkoolikaaslased ning muud sama põlvkonna inimesed, et täiskasvanuks kujunemise - suguküpsuse ja seksi teemat varem ei olnud, seda ei käsitletud ei kodus ega koolis.

Ilmselt kuulusime just meie - kui kasutada Tammsaare terminit - n-ö vurlede e linnastunud, oma päritolukeskkonnast väljaspoole sattunud inimeste põlvkonda. Meil polnud enam kodust laudakogemust nagu taluinimestel. Kuigi ka varem ei olnud tavaks intiimsetest teemadest rääkida, saadi sedalaadi teadmisi loomade analoogiast (nt noorloomade sündimine, lehma indlemine). Hiljuti ilmunud võrumurdelises raamatus "Lapsepõlve suve" (Kaplinski 2019) räägib kirjanik Jaan Kaplinski, kuidas maalapsed tema kui linnapoisi lehma paaritamise juurde viisid, ja kohe sai selgeks, kuidas asi käib. 1930. aastatel ja hiljem sündinud haritlaste põlvkond oleks saanud vastavaid teadmisi ehk vaid raamatutest, mida ju siis ei olnud. Sõjaeelse tõlkelise "Abielutehnika" populaarsusest Vestholmi gümnaasiumi abituuriumipoiste valgustajana 1954. aastal kirjutab mu paralleelklassis õppinud Heinz Valk oma mälestustes (Valk 2011: 168-169). 


\section{Salastatud sissetulekud: palk ja varanduslik seisund}

Palgalehed olid Nõukogude ajal kollektiivis ühised ja avatud. Igaüks andis raha saades samale lehel allkirja, direktorist koristajani. Muidugi olid mõnedel veel teised palgalehed ka, mida ei teatud - eriliste teenete eest. Palku hakati salastama pärast nõukogude aja lõppu, tavapäraseks sai palga kandmine pangaarvele ja summat teab sageli ainult saaja.

Vestlustes tuttavatega vähendatakse palganumbrit mõnigikord, ümardatakse ikka allapoole. Kas häbenetakse, et sissetulek suurem kui vestluskaaslasel? (kursusekaaslased)

Palga suuruse teed ise saladuseks. Mida suurem palk, seda vähem räägitakse. Olime Merikesega samal positsioonil, et kumbki ei teadnud (polnud kunagi küsinud) oma poja palka: ainsana oli teada, et on piisav äraelamiseks, tuleb toime (Merike, Pille)

Olin Soomes kolleegil ja sõbrannal külas. Meil oli palju ühiseid vestlusteemasid. Kord tuli ka sissetulek kõne alla. Esko kiitis, et Pirkko-Liisa juhatajatöö on küll raske ja temale eriti ei sobi, aga palk on... "Älä puhu kaikesta!" katkestas proua, ja jutt jäi sinna. (Pille)

\section{Häbenemine, salatsemine või valvelolek}

Vaikimise ja häbenemise või valveloleku põhjusi võis sõjajärgsetel aastatel olla mitmeid. Paljud kaanonid või seisukohad muutusid koos elumuutustega, aga vanemal põlvkonnal oli raske uuendustega kohaneda. Küsitletud meenutasid, et omal ajal tunnistati vaid abielulist kooselu ja väljaspool abielu sündinud last peeti häbiväärseks. Häbeneda võidi oma keelemurret, rahvust või päritolu. Tuli valvel olla, kuidas ja millal tuttavatega suhelda, et ei satuks ka valitsevate poliitiliste seisukohtadega vastuollu.

Kui tädi Elli (1893) pärast lapselapse Ivari sündi (1956) turult tulles eemalt kedagi tuttavat nägi - oma täditütart või mõnda muud, kellega igapäev kokku ei puututud, astus kohe lähimast hooviväravast sisse ja ootas, kuni tuttav mööda läks - et poleks vaja seletada, kuidas lapselaps kasvab või et kuidas tema tütrega nü̈̈d ometi niimoodi juhtus. Tütar oli abiellunud, aga kuna elu ei sobinud, koliti lahku ja kummalgi oli uus pere. Sündinud lapsesse suhtusid vanemad sugulased kui vallaslapsesse. 
Mituteist aastat noorem õde Linda (1909) talus oma lapselapse Jaagupi (1976) sündimist vist kergemalt; ütles vaid, et mis sa siis nii hiljaks jätsid, me oleks saanud rohkem aidata. Vanaisale oli ainuke meessoost järeltulija väga tähtis. Elli-tädi järgmine õde Liide (1895), üksik inimene, olnud Ivari sündimise järel väga õnnetu: "Ma olen meie peret ikka paremaks pidanud ja igaühe kohta halvasti öelnud, kui midagi teistmoodi on. Ja vat nüüd!” Ülejärgmine õde Olga (1900), ka üksik, aga väga suur laste sõber, lisanud: "No mis sa siis oled igaühe küljes hammastega kinni! Mina ei häbene midagi.” (Pille)

Ada (1929) häbenes oma päritolu, sündimist Leningradis. Tema Eestis elanud isapoolsed sugulased ei võtnud teda kaua omaks, ikka et venemaaeestlane - Ada isa oli sündinud Eestis, aga ema Gattšinas, vist kolmandat põlve sealne. Nii ta sellest ei rääkinudki. Ada lõpetas Tartu ülikooli soomeugri filoloogina (1955), aga tal oli veel hiljem tegemist kodakondsuse saamisega - nõuti ikka eesti keele eksamit! Ada jutustas oma päritolust vabalt alles siis, kui mu õde abiellus teistkordselt-Pihkva oblastis sündinud ja saksa ajal noorukina Eestisse toodud mehega. Muuseas, selle mehe (onu Mihkli) ning samavanuse tädipoja sünniaastat muudeti ja salati, vaikiti: sõja ajal Eestis passi saades vähendati poiste vanust 2 aasta võrra (1926st 1928ks), et poleks vaja saksa sõjaväkke minna. Ei olnudki, poisid saadeti kooli. Tädipoeg taastas oma sünniaasta vana alleshoitud sünnitunnistuse alusel kunagi hiljem, onu Mihkel pidi pensioni paar aastat kauem teenima. (Viivi, Pille)

Kui elasime Kosejõel ja isa oli seal juhataja (1945-1951), käis meil vahel külas onu Petersoo, isa koolivend Tallinna Pedagoogiumi päevilt. Küll ta meeldis mulle! Me mängisime lumehelbekest; ma peitsin ennast isa kasukasse ja lehvisin nii toas ringi. Kord tuli ta mulle kooliteel hobusega vastu, ütlesin tere, aga ta ei vastanud, vaatas kohe teisele poole. Nagu poleks näinud ega kuulnud. Ise alles hiljuti käis meil. Rääkisin isale, et niisugune lugu. Siis isa seletas, et see onu on praegu salamees, teda nagu ei tohiks olla ja temast ei tohi midagi ega kusagil välja teha. Ta peab salajas elama, muidu läheb tal halvasti ja meil ka. Ja siis oleme nii, et me õues ei näe ega tunne, et teda nagu polegi. Onu Petersoo elas kusagil Kose kandis oma abikaasa sugulaste juures, käis talvel hobusega metsast puid toomas ja heinu vedamas, siis sõitis meilt mööda. Vahel harva käis koos prouaga meil külas, õhtul ja tasa. Sellest ei olnud vaja rääkida. Onu jutustas, mis päeval ta jälle meilt mööda sõitnud ja isa näinud oli, et mis isa tegi ja... Aga päeval ta ei andnud end tunda. Kord palunud ta 
isalt abi, rahalist abi. Lapsed käisid ju linnas koolis ja pere oli hädas, naine lasti ametist lahti. Isa vist aitas, aga emale see eriti ei meeldinud. Ega ju õpetaja palk pole Eestis kunagi suur olnud; aga meie isal oli süda oigel kohal. (Viivi)

\section{Poliitiline hirm, ettevaatlikkus ja pained}

Kõige tähtsama või mõjukama tabuteemana meenus küsitletutele poliitiline hirm ja sellest tingitud ettevaatlikkus. Meenutati, et tuli jälgida, mis laule julgeti laulda või kirjutada oma laulikusse, millise kirjaniku raamatud tohtisid või ei tohtinud riiulil olla, millise valitsuse ajal ei saanud leinata, kui poeg hukkus Laadogal või vend saksa sõjaväes, ning mäletati põhjuseid, miks see, kes oli kirikuinimene, ei saanud pidada kooliõpetaja ametit. Niisuguste piirangute tajumine õpetas ettevaatlikkust, tunti, et oldi sunnitud vaikima, ridade vahelt lugema ja mõistma.

Alustasin 6. klassis käsikirjalise lauliku kirjutamist (30.10.49). Omaette lugu oli, kuidas üldse kaustik saada õnnestus - poes ju (sõja ajal ja pärast sõda ka) polnud. Ema vaatas, mida kirjutan, ja hoiatas: "Kirjuta-kirjuta, aga vaata, et Siberisse ei saadeta!" (Pille)

Algkooli ajal olid salmikud, mille järgi oleks võidud küll kinni panna - nii palju Eesti Vabariiki ülistavaid luuletusi ja salmikesi! Keskkooli lõpul olid laulikud igaühel! (Marja)

Ebasoovitavad raamatud ja käsikirjad olid poliitiliste kahtlustuste aluseks. Haapsalu jääpurjetaja Vaiko Vooremaa ema, omaaegne Märjamaa kooli algklasside õpetaja jutustas ühes raadiosaates, kuidas teda tunnist välja kutsuti, sü̈̈distus anti ja üsna varsti Siberisse saadeti. Põhjuseks oli, et tema käsikirjalisest laulikust lauldud mingil hiljutisel õhtul ebasobivaid laule. Laulik pärinenud saksa-ajast ja selles oli ilmselt ka tollaseid poliitilisi laule. Meie ema kartis väga Siberisse saatmist - meil olid mitu aastat vastavad riided õmmeldud ja valmis pandud; veel kartis ta, et isa jälle midagi valimatut ütleb, nii nagu mõtleb: "No küll see isa meid Siberiks valmistab!” (Pille)

Ema ei käinud kirikus. Ütles, et tahab oma koolmeistriametit pidada ja kui see nõukogude korrale ei meeldi, siis ta valib oma ameti ja loobub kirikust. Pere tutvusringkonnas oli niisuguseid häid tunnustatud õpeta- 
jaid, kes oma usulise veendumuse või tegevuse pärast pidid ametikohast loobuma: 1. Gustav Ferdinand Nõlvak, isa kolleeg Koluverest, loobus oma baptistikoguduse nimel kooliõpetaja kohast Haapsalus; 2. LääneEuroopas erivajadustega laste kasvatamise alal õpetust saanud ja Udriku hooldekodu ning Kosejõe koolkodu rajanud Hugo Valma vabastati viimaselt kohalt Kosejõel kohe, kui ta oli sooritanud konsistooriumis vaimuliku õpetaja eksami; 3. Filoloog Georg Liivi ema mattis oma mehe kiriklikult ja lasti Haapsalu gümnaasiumi vene keele õpetaja kohalt lahti. Filoloogiadoktor August Annisti (1899-1972) vist viimasel sünnipäeval tema kodus olid külalisteks tema tütred ja mõned folkloristid. Kõne alla tulid ka poliitilised teemad. Minu kõrval istuv Annist astus mulle korduvalt valusasti keelavalt jala peale, kui arvas teema poliitiliselt liiga kardetavaks muutuvat. Aga Annistil oli hiljutine 6-aastane vanglakogemus (1945-1951), mis sellest, et ta hulk aega pärast surma sü̈̈tuks tunnistati ja rehabiliteeriti. (Pille)

Poliitikast meie peres ei räägitud, kü̈̈ditamisest ka ei räägitud. Vist kardeti või ei teatudki sellest midagi. Igaüks elas rohkem omaette. Sõbranna peres räägiti pahasti venelastest, neid vihati, ei lubatud last pioneeriks astuda. Mina astusin, mulle meeldis, olid toredad koondused. (Merike)

Mu vanem vend oli saksa sõjaväes, sai 1944 Kuramaal surma. See teatamine ja surmast teadasaamine oli nii juhuslik. Vennanaine tahtis uurida, sõitis - läbi sõja... Jõudis Saksamaale, koos aastase lapsega. Kui tuli tagasi, ei lastud Tartus elada. Kolis Meerapalusse, isa juurde, talusse. Tema asjadest ei räägitud üldse ega mitte kellelegi. See oli vene ajal tabuteema. (Eha)

Tartu kommunaal-kaubanduskoolil ja ärinduskeskkoolil oli ajakiri. See lõpetati kohe 1940ndal, sellest ei räägitud enam kunagi. Ma olin siis kodutütar, enne sõda. Siis pärast see teema kuulus tabuteemade hulka, sellest ei räägitud. (Eha)

Väliseestlane Hilja Wescott lahkus Eestist lapsena 1938. aastal USAsse. Ta käis koos oma itaallasest ja foneetikust abikaasaga Tallinnas foneetikakongressil (1987). Otsis Siselinna kalmistu lähistelt Kalevi staadioni kohalt oma kunagist kodumaja. Hiljem meenutas Eestis elatud aegu-et oli üks ilus laul, "Mu isamaa...", et kuidas see laul oli? - "Mu isamaa on minu arm”, pakkusin mina kohe... - "Ei-ei, oli midagi muud!” Hakkasin oma pakutud Ernesaksa laulu laulma ja jutt jäi sinna. Küllap ta meenutas 
hoopis Eesti hümni. Ma oskasin ju seda küll, aga ei hakanud pakkuma. Rahva hulgas vist ei oleks julgenud laulda ka. (Pille)

Üliõpilaslaulupidude puhul tehti 1960.-1970. aastail väikesi Tartu vappide ja sümbolitega kaelarätte. Ilusad ergud värvid ja mitmesugused värvikombinatsioonid. Mul oli ühel hommikul kaelas sini-must-valgete servatriipude ja pruun-kollaste vappidega rätt heleda kleidi peal. Järsku hüüab kena kolleeg Aldi, murdeuurija: "Oi, Pille! No mis sini-must-valget demonstratsiooni sa siin korraldad?!” Kõik vaatasid. Mis see siis oli? Kas ikkagi valvsus? Kõik ju teadsime, mida see värvikombinatsioon tähendas. Ebamugav oli. (Pille)

Isa viidi ära, kui olin 7. klassis. Elasin isa juures, käisin Tallinna 10. Keskkoolis. Auto peatus öösel maja ees, siis viidi... Pärast elasin ema juures Türil, käisin Paide keskkoolis. Kartsin kuni ülikooli ajani, kui mingi auto maja ette sõitis, eriti pimedas. Türil elasime peatänava ääres, seal oli ikka autosid. Ühiselamus Tartus olid aknad teisele poole, autod ei sõitnud, siis läks [hirm] üle. (Merike)

Nõukogudeaegne elu - see oli suur kahekeelsuse õpetus. Poliitikast me ei rääkinudki, seda teemat ei olnud olemaski. Ei teadnud ka kuigi palju. Oli muidugi ohtlik rääkida, koputajad ja... Olime harjunud, ei tajunudki. (Merike)

Meie põlvkonda hoiti eemale kõigest - sõjaeelsest kirjandusest ja väliseesti kirjandust justkui poleks olnud olemaski. Ei tohtinud... Aga mu keskkooli õpetaja Võrus (ma ei ütle ta nime)! rääkis meile kõigest, kogu Eesti ajaloost. Kõigest. Sageli tuli aru saada ridade vahelt. Aga ridade vahele kirjutamine, sellest arusaamine, mõistmine, väljapeilimine - see oli põnev ka. Keegi ei kaevanud ja midagi ei juhtunud. (Helga)

Vaikimine, ka pausid, tähendasid vahel rohkemgi. Pausidest sai välja lugeda. (Elsa)

Isa kinniolemist on küll korduvalt küsitud. Ülikooli sisseastumisel (1954) mind kutsuti ka välja. Ei tahetud vastu võtta... Et miks isa kinni on? Miks te seda varjate? No ei lähe ju ise rääkima, et isa on kinni - no kellele ma rä̈̈gin? - "Aga teil on medal - me peame teid vastu võtma.”Võeti filoloogiasse, kuhu tahtsin. Siis Soome-sõidu ankeedid, kui juba Soomega ühendust oli - et isa oli kinni, mis paragrahvi järgi? Isa ise ei tahtnud 
rääkida - ikka see 58 ja... et mis lõige? Isa oli koos Riho Pätsi ja Alfred Karindiga, 1947. aasta laulupeo dirigendid viidi ju puha ära. Anu Kõlar on seda uurinud - ei pidanudki midagi olema... sü̈̈di lihtsalt mõisteti. Isa sai algul rohkem (25+5), siis jäi 10 peale, tegelikult oli 6 aastat. Ta oli Narvas ja Vasalemmas. Sinna oli 7 kilomeetrit jaamast. Käisin isa vaatamas, rääkimas. Saime juttu ajada. Valvurid rääkisid kõigiga "sina" - oli solvav, keskkoolis ju teietati... Isa oli ajakirjanik, saksa ajal kirjutanud ajalehtedesse, seal oli tema artikleid - "Eesti Sõnas” ja Koidula tähtpäevast ja... (Merike)

Hakkas palju kergem, kui selgus, et ei pea enam varjama. Olin pärast Igori sündi 2 aastat töölt ära. Kui Raadiomajja tagasi läksin, kutsuti mind varsti partorgi juurde - meil oli niisugune nomenklatuurne mees, parteikomiteest, mitte ajakirjanik. "Nü̈̈d lõpuks võid parteisse astuda! Läksid venelasele mehele!” - "Ei! Abiellusin armastusest!” Paljud ju võtsid vene naised - see andis nendele rohkem võimalusi, aga paljud võimalused ka kadusid. Raadiokomitee esimehe kolm poega ei saanud tulla laste laulustuudiosse - nad ei osanud eesti keelt, nende ema oli venelane. (Merike)

Vanaema oli hirmul. Tegelikult ta tapetigi, oma kodus, 1947. aastal. Arvati, et naabri sulane tappis. Saksa ajal oli tapetud teine pere - need olid tüli, varanduse või päranduse asjad, niisugune olukord seal. Vanaema käinud metsas. See sulane tulnud vastu, kaks paari saapaid olnud ôlal ja käed olnud verised. Läksid mõlemad edasi, vanaema tegi, nagu ei näekski teda ja tema ka... ja läksid niiviisi, et ei näinud teineteist. Aga ehk see sulane kartis, et ehk räägib ära... Aga seal olid ju venelased metsas, sõjaväelased, sõja ajal; nad ei pääsenud sakslaste tulekul Hiiumaalt minema - laeva polnud. Ja pärast ei räägitud nendest enam.

Küsija: Kas midagi oli ära viidud, kui vanaema...?

Liha oli ära viidud, sealiha. Keegi ei läinud kaebama, polnud ju tõendeid. Pärast pandi ta kinni, see sulane. Siis ükskord hiljem tädi rääkis - onu Lembitu särk olnud seljas... - "Ah mis sa sest vaatad, vana särk.” Aga see oli Lembitu leerisärk, hoidsime ikka alles. Oletasime, et tal ikka oli hirm meie pere ees. Tegelikult oli ka kaudne hoiatus. Naabri poeg öelnud tädile, et teie ema seal üksi, elab päris üksi, et pole hea, kui ta seal üksi on... Tahtsin küsida, aga enam pole kellegi käest küsida. (Luule)

Elvi vend Albert oli onu Lembitu sõber. Kuulusid mõlemad mopi alla. Kutsuti sõtta, 1941 Lembit läks, aga Albert laskis vene sõjaväest jalga. Oli esialgu metsas, siis läks Soome, sealt Rootsi, Kanadasse. Ükskord - see 
pidi olema saksa ajal - käis meil, rääkisid vanaemaga. Vanaema oli hommikul vaikne, ei rääkinud: "Ah, pole midagi...” Saksa ajal, siis vanemale tütrele Olgale Albert rääkinud, et Lembit sai Laadoga peal surma, läksid miini otsa. Neid asju lapsele ei räägitud. Mina kuulsin tädi käest alles palju hiljem. Vanaema rääkis oma asju vanemale tütrele Oljale. Tema oli sündinud 1908, Lembit 1921, nii et ta oli nagu venna lapsehoidja või... Olja ei rääkinud kellelegi, oli kindel ja tubli, oskas vait olla. Hiiumaa tädile Taiule ka ei räägitud, vanema venna surma ka ei rääkinud. Taiul oli vähe sõpru. Oli üks Marjana, see käis venelastele kaebamas - seda ei sallitud, et ehk Taiu räägib sellele. Mulle ka ei räägitud. Lastele raskeid asju ei räägitud. (Luule)

Neljakümne üheksanda märtsis, koolivaheaja lõpul ema kontrollis ja soris raamatukapis, andis raamatuid minu kätte. Kaminas oli tuli, ma pidin need raamatud ära põletama. Oli "Eesti rahva kannatuste aasta" ja "Nimed marmortahvlil", oli veel muudki, mis polnud varem mu kätte sattunud. Nutsin, lugesin ja põletasin, ema käskis. Muist panime kastidesse: Tuglas ja Parijõgi ja Mälk ja Under, kes pidid olema keelatud. Kastid viisime puukuuri ja ma ladusin kogu virna salaja ümber, peitsin kastid puude alla. Kui millalgi järgmisel aastal neid vaatama läksime, olid kõik kastid tühjad, ei mingit märki. Sellest ei tohtinud kellelegi rääkida. Hiljem kuulsin, keda õpetajatest kahtlustati... et antikvariaati. (Pille)

\section{Inimeste klassifitseerimine, juudivastasus}

Üldiselt tuli meenutusi rahvuse alusel halvustamisest mälestustes ette vähe. Sõjajärgse põlvkonna lastena ei tundnud me ei seisuslikku ega varanduslikku kihistumist. Sõda oli kõik nivelleerinud, kaotanud ka baltisakslaste ja juutide kogukonna ja rahvusliku kultuurautonoomia. Tavaelus hakati tundma "suure venna" ja tema keele eelistamist, seda isegi kritiseeriti, aga enamasti mitte laste seltskonnas - nende eest hoiti näiteks saladuses, et vene keel on ametlikult koolides vabatahtlik.

Males pole Eestis antisemitismi probleemi. Moskvas, Venemaal oli see mitmelgi alal suur probleem. Siin pole juudiprobleemi olnud. Leningradis oli võimatu töötada - egas muidu Lotman ja Stolovitš ja mitmed muud poleks siia tulnud ja edukalt edasi töötanud. Siin oli teistsugune suhtumine; hinnati inimese tarkust, rohkem isiku kui rahvuse tasandil. Minu poeg Igor sündis Moskvas. Olime 14 inimest palatis. Ühel õhtul - 
suur juutide kirumine... Siis vaatasin, üks Valja - teki all, tasa... Kas ei pandud tähele või ei tahetud tähele panna? Läksin istusin tema voodile, võtsin käest kinni.

Küsija: Kas ei pandud sulle pahaks?

Ei! Minusse suhtuti hästi, kogu Baltikumi suhtuti Moskvas hästi.

Meie kõrvalkorterisse Mustamäel kolis üks venekeelne pere. Mul oli hea meel, et kui babuška Moskvast siia tuleb, on tal kellega suhelda. Babuška ju kaebas, et Mustamäel kõik räägivad eesti keelt ja tal pole siin kellegagi... - "Ei-ei, nendega ta ju ka ei räägi," ütles babuška poeg, minu mees Boris. Meie uued naabrid olid nimelt juudid. (Merike)

\section{Tabu murd(u)mine või avalikukstulek}

Aastakümneid kehtinud keelud ja vaikimisvajadus valitsesid inimeste mõtteid ja ellusuhtumisi sügavalt ja kaua. Nendest vabaneti lõpuks vähehaaval. Mälestusi jaganud inimesed on nüüdseks vanemad, kogenenumad, kunagised emotsioonid pole enam nii tugevad ja värvikad, paljugi on ununenud. Ometi püsivad mõned kaua painanud tabulised seigad meeles.

Tabu murd(u)mine - esimene, tähtsaim mälestus: olime Andresega 1988. kevadel muinsuskaitse üritusel Tartus, seisime EÜS-i maja ees. Palju rahvast tänaval, ootavad nagu midagi, pingeline vaikus. Järsku hakkab Henn Käämbre lugema Gustav Suitsu: "Kas te tunnete: väriseb maa. Kas tunnete, kuulete: rebeneb taevas?" Kohe kergem hakkas, kuigi olukord oli ärev - nagu mingit lahendust oli tunda. (Mari)

1953. aasta. Konservatooriumi rektoriks oli siis Eugen Kapp. Tulevane helilooja Vello Lipand ei saanud sisse - peres oli poliitilisi põhjusi või..., et ei tohtinud vastu võtta. Siis, järgmisel aastal või millalgi-Kapp kõnnib nende aia taga, Nõmmel. Tuleb väravast sisse, tuli ise kodunt otsima: "Meile tulid uued eeskirjad, me saame teid nüüd vastu võtta." (Marja)

Sõja ajal, aga ega hiljemgi ei räägitud 1930-ndatest aastatest, sõjaeelsest ajast ... meie peres ei räägitud. Alles nü̈̈d, hiljem, võis sellest julgemalt rääkida. Aga tädid ja vanaema elasid ju sel ajal! Mul oli hea allikas, kust oma huvile vastusesid sain, kui taipama hakkasin ja ise küsisin. Kasutasin nende teadmisi oma lavastajatöös Estonias. (Mart Sander ja ema; ERR: Käbi ei kuku, sept 2019) 


\section{Kokkuvõte}

Artikli eesmärk oli anda ülevaade tabudest ja mahavaikitud teemadest argisuhtluses ühe samaealiste tutvuskonna näitel. Küsimused selle kohta, millest pere(de)s ei räägitud, viisid enamasti küsitletute mõtted lapsepõlvele. Praeguseks pensioniikka jõudnud inimestel langes see periood kas sõja- või sõjajärgsesse aega. Perekonnas või kollektiivis välditi ohtlikuks peetud, valusaid või ebameeldivaid teemasid ja õpetati seda ka lastele. Kui lapse küsimustele ei osatud või ei tahetud vastata, hoiatati liigse pärimise korral ruttu vanaks saamisega. Olukorras sobimatut täiskasvanute jutuhoogu vaigistati sõnatu susinaga või õpetliku lausega: Tasa, tasa, karu tuleb! või vanasõnaga: Metsal silmad, kõrvel kõrvad! Piisas ka vaikselt sõrme suule panemisest, müksamisest või jala peale astumisest. Kogutud meenutuste hulgas kajastati ootuspäraselt rohkesti ettevaatlikkust, hirme ja keelde - uurijad on nimetanud Teise maailmasõja järgset põlvkonda lausa "vaikivaks põlvkonnaks" (vt pikemalt Jõesalu 2018), kuid mälestuste keskmes on siiski enamasti jutustaja või tema kirjeldatud isikute elu, millele paralleelselt toimunud ajaloosündmused moodustavad vaid raami.

Olulise ja kahetsetava teemana meenusid paljudele laiema silmaringiga inimestele perekonnaloo õigel ajal rääkimata-kuulamata-küsimata asjad. See on niisugune teave, mida kannab ainult perekond ja mis kaob vanema põlvkonna lahkumisega. Niisugused teadmised võimaldavad avada oma suguvõsa, tutvusringkonna, lõpuks kogu rahva vaimset elu ja saatust. Paaril viimasel aastakümnel avaldatud arvukad mälestusraamatud aitavad seda lünka täita.

Mälestuste rääkijad meenutasid, et tervis oli nende nooruses peresisene asi, õnnetustest ja haigustest tavaliselt võorastele ei räägitud - aga just seda küsib mõnigi praegune tohter, kuna varasemaid põlvkondi puudutavad terviseteadmised aitavad tänapäeva inimeste ohtusid ette näha. Praegused vanavanemad kadestavad lapselapsi, kellele juba lasteaiast alates keha ja selle muutuste kohta selgitusi jagatakse - eelmistel põlvkondadel seostus selle valdkonnaga mitmeid tabusid.

Materjalist ilmnes, et sarnaselt isiku- ja terviseandmetega hoitakse tänapäeval enda teada ka palganumber. Paljudes peredes oli varem avaliku palgalehe kõrval ka ühine rahasahtel, nüüd ei tea sageli isegi abikaasa, kui suur on tegelikult teisepoole palk.

Mingi seisundi või olukorra häbiväärseks või hädaohtlikuks pidamise osas on ajaga palju muutunud, mõnedki uskumused ja tabud on kadunud või lahjenenud. Ebaõnne hirmus hoidsid sõjajärgsed põlvkonnad saladuses isegi seda, kui noored kurameerisid või olid pulmad tulemas. Samuti kandis "õrnas seisundis" naine laia hõlsti, et keegi ta seisundit ei märkaks (kardeti näiteks kurja silma), nüüd riietub lapseootel noorik sageli eriti silmatorkavalt. Samas ei 
räägita perestruktuuri muutumise tõttu enam vallas- ja võõraslastest; "moodi" on tulnud ümbersõnastamine kärgperedeks.

Paljude sõja järel Eestisse tulnud või sattunud perede liikmetel pole tahtmist varasemas elus üleelatust järeltulijatele midagi rääkida, poliitilised pained on siiani segamini argielu muredega (Kippar 2000).

Ka kohalikel sõjaaja lastel ja noortel on peaaegu kõigil poliitilise hirmu kogemusi ja üleelamisi (vrd uurimusi sõja- ja sõjajärgsete traumade kajastumisest ja mahavaikimisest perepärimuses nt Latvala 1999, Aarelaid-Tart 2006: 153 jj; Jaago 2018). Meenutuste järgi olidki need vaikimised kõige raskemad. Vaikimise taga oli sageli kogu pere saatus: kui oskasid suu kinni hoida ja keegi teada ei saanud, läks hästi, vastasel korral ootas peret laialipillutamine, kodust ilma jäämine või muu löök. See tunne jäi kogu eluks, tegi paljudeks aastateks ettevaatlikuks ja pani valima, millest rääkida ja millest mitte.

\section{Kirjandus}

Aarelaid-Tart 2006. Cultural Trauma and Life Stories. Vaajakoski: Kikimora Publications. Jaago, Tiiu 2018. Trauma ja elulood. Mäetagused 71, lk 112-142 (doi: doi:10.7592/ MT2018.71.jaago2).

Jõesalu, Kirsti 2018. We were children of romantic era': nostalgia and the non-ideological everyday through a perspective of "silent generation". Kõresaar, Ene (toim). Baltic Socialism Remembered: Memory and Life Story since 1989. Routledge Taylor \& Francis Ltd, lk 127-147.

Kippar, Pille 2000. Kolmanda põlvkonna kujundajad. Jürgenson, Aivar (koost, toim). Eestlane ja tema maa. Konverentsi "Kodumaa ja kodupaik: eestlase territoriaalne identiteet” (16.-17. november 1999) materjale. Tallinn: Ajaloo Instituut, lk 224-239.

Korkiakangas, Pirjo 1997. Individual, Collective, Time and History in Reminiscence. Ethnologia Fennica (Finnish Studies in Ethnology 25), lk 5-16.

Kõresaar, Ene 2003. Lapsepõlv kui ajaloopilt. Rahvuse ja riigi metafoorne kujutamine vanemate eestlaste lapsepõlvemälestustes. Kõresaar, Ene \& Anepaio, Terje (toim). Mälu kui kultuuritegur: etnoloogilisi perspektiive. Studia Ethnologica Tartuensia 6. Tartu: Tartu Ülikooli kirjastus, lk 60-91.

Kõresaar, Ene (toim) 2005. Elu ideoloogiad: kollektiivne mälu ja autobiograafiline minevikutõlgendus eestlaste elulugudes. Tartu: Eesti Rahva Muuseum.

Latvala, Pauliine 1999. Soomlase elu kujutamine pärimuslikus ajaloos. Mäetagused 11, lk 72-87 (doi:10.7592/MT1999.11.latvala).

Marcus, George 1993. Past, Present and Emergent Identities: Requirements for Ethnographies of Late Twentieth-Century Modernity Worldwide. Lash, Scott \& Friedman, Jonathan (toim). Modernity and Identity. Blackwell: Oxford, Cambridge, lk 309-330.

Valk, Heinz 2011. Lugu poisist, keda kallistas ilus pastoriproua. Tallinn: Menu kirjastus. 
Summary

\title{
"Curiosity killed the cat!" Taboos and hushed-up topics in everyday communication on the example of a peer community
}

\author{
Pille Kippar \\ Professor Emeritus \\ School of Humanities, Tallinn University, Estonia \\ piki@tlu.ee
}

Keywords: delicacy, experience stories, family folklore, political fear, silence, taboo narratives

There have always been topics in human communication which are not shared or discussed with anyone. Approaches and attitudes also differ by generations. This article opens the topic of silence from the viewpoint of my own generation - those retired by today. The article is based on the data collected via direct interviews and discussions from about half a hundred informants, and in addition to that also memories and indirect observations as well as radio broadcasts. My questions were concerned with undiscussed or taboo topics in families, work or friends' communities but also among casual acquaintances or total strangers. The topic of discussions expanded as is characteristic of folklore: one word grew out of another and one story from another one. I grouped the most significant repetitive motifs into topic areas. It turned out that for years people have kept silent about family secrets, diseases, sex, relatives who fought on the 'wrong' side of the front or fled into exile. The most frequent reasons for the silence were attempts to save someone from resentment or an unpleasant situation; taboos also emerged due to official prohibitions and orders as well as caution due to political circumstances.

Pille Kippar on folklorist, kes on uurinud eesti ja teiste läänemeresoome rahvaste loomamuinasjutte ning koostanud eesti loomamuinasjuttude kataloogi. Alates 1984. aastast on ta Rahvusvahelise Rahvajutu-uurijate Seltsi (ISFNR) liige, 1989. aastast Rahvusvahelise Etnoloogia ja Folkloristika Ühingu (SIEF) liige ja aastast 1993 Kalevalaseura liige. Alates 1964. aastast on ta olnud Tallinna (Pedagoogilise) Ülikooli rahvaluule õppejõud, samuti pidanud arvukalt loenguid ühingus Teadus.

Pille Kippar is a folklorist, member of the International Society for Folk Narrative Research since 1984, member of the International Society for Ethnology and Folklore since 1989, and member of the Kalevalaseura since 1993. She has studied Estonian and other Finno-Ugric peoples' animal fairy tales and compiled a catalogue of Estonian animal fairy tales. Since 1964 lecturer of folklore at Tallinn (Pedagogical) University; has delivered plenty of lectures on popular education at Teadus (Science) Society.

piki@tlu.ee 